\title{
Targeting Argonaute to chromatin
}

\author{
Jered M. Wendte ${ }^{1}$ and Craig S. Pikaard ${ }^{1,2,3}$ \\ ${ }^{1}$ Department of Biology, Indiana University, Bloomington, Indiana 47405, USA; ${ }^{2}$ Department of Molecular and Cellular \\ Biochemistry, Indiana University, Bloomington, Indiana 47405, USA; ${ }^{3}$ Howard Hughes Medical Institute, Indiana University, \\ Bloomington, Indiana 47405, USA
}

\begin{abstract}
In many eukaryotes, siRNAs bound to Argonaute proteins guide chromatin-modifying enzymes to complementary loci, resulting in transcriptional gene silencing. Multiple lines of evidence indicate that siRNAs base-pair with longer RNAs produced at target loci, but the possibility that siRNAs base-pair directly with DNA remains an attractive hypothesis. In a recent study, Shimada et al. (pp. 2571-2580) conducted experiments that address these alternative hypotheses, yielding additional evidence that fission yeast siRNA-Argonaute silencing complexes are recruited to target loci exclusively via interactions with nascent transcripts.
\end{abstract}

RNA-mediated transcriptional gene silencing is widespread in eukaryotes. The process is particularly well studied in Schizosaccharomyces pombe and Arabidopsis thaliana, which have in common the fact that the requisite siRNAs are diced from double-stranded precursor RNAs made via the combined actions of DNA-dependent and RNA-dependent RNA polymerases. The siRNAs are then loaded into Argonaute (Ago) proteins that nucleate assembly of multiprotein silencing complexes at loci that are complementary to the siRNAs (Holoch and Moazed 2015; Wendte and Pikaard 2016).

In both $S$. pombe and $A$. thaliana, evidence indicates that silencing complexes are brought into proximity of chromatin through base-pairing interactions between siRNAs and nascent RNAs generated at the target sites. In yeast, these nascent RNAs are generated by RNA polymerase II (Pol II), whereas, in Arabidopsis, they are generated by Pol V, a plant-specific evolutionary derivative of Pol II (Wendte and Pikaard 2016). Studies in both organisms have demonstrated that target loci need to be transcribed in order to be silenced and that Ago can be coimmunoprecipitated in association with RNAs derived from silenced loci (Motamedi et al. 2004; Irvine et al. 2006; Wierzbicki et al. 2009; You et al. 2013). Shimada et al. (2016) provide additional evidence that RNAs generated at target loci, and not just the act of transcrip-

[Keywords: heterochromatin; RNAi; noncoding RNA; epigenetics; nascent transcript]

Corresponding author: cpikaard@indiana.edu

Article is online at http://www.genesdev.org/cgi/doi/10.1101/gad.294900. 116. tion, are required for transcriptional gene silencing (TGS). They engineered the production of siRNAs that match intron sequences within a reporter transgene, showing that intronic sequences placed near the $3^{\prime}$ end of the transgene allow for efficient TGS. In contrast, relocating the intron nearer the $5^{\prime}$ end of the target transgene, where the intron is more rapidly removed by cotranscriptional splicing, reduced the likelihood of TGS. If Ago-siRNA complexes were recruited via direct interactions with transcribing Pol II rather than Pol II transcripts, one would not expect intron position to be important.

The results of Shimada et al. (2016) also have important implications with regard to the possibility of siRNADNA base-pairing in TGS. In plants, the possibility of siRNA-DNA interactions has been considered to explain the precision of RNA-directed DNA methylation as well as the observation that artificially induced siRNAs can trigger DNA methylation of homologous transgene sequences in the absence of detectable transcription of the transgene (You et al. 2013). However, mutating active site amino acids of Pol V abolishes most TGS in Arabidopsis, indicating a need for transcription, as in yeast (Wierzbicki et al. 2009). One can imagine a scenario in which ssDNA generated during the process of transcription might provide opportunities for siRNA binding. The displaced nontemplate strand of the transcription bubble is one possibility but is a transient and rapidly moving target. Persistent RNA-DNA hybrids, displacing one DNA strand as an R loop, would generate longer-lasting ssDNA targets and have been identified at sites of TGS in $S$. pombe and correlated with the establishment of silencing marks (Nakama et al. 2012). Moreover, RDM1, a TGS protein in Arabidopsis, is a ssDNA-binding protein in vitro, inviting speculation that it might play a role in stabilizing single-stranded regions associated with Pol V transcription (Pikaard et al. 2012). With these considerations in mind, the finding by Shimada et al. (2016) that splicing of proximal intronic sequences reduces TGS strongly sug-

(C) 2016 Wendte and Pikaard This article is distributed exclusively by Cold Spring Harbor Laboratory Press for the first six months after the full-issue publication date (see http://genesdev.cshlp.org/site/misc/ terms.xhtml). After six months, it is available under a Creative Commons License (Attribution-NonCommercial 4.0 International), as described at http://creativecommons.org/licenses/by-nc/4.0/. 
gests that the base-pairing interactions are functionally occurring with the nascent RNA and not the associated DNA, where the intronic sequences are still present. One can argue that the results do not formally rule out the possibility that Ago-siRNA complexes initially bind to nascent RNA but subsequently engage the corresponding nontemplate DNA. Alternatively, one might reconcile the results from Shimada et al. (2016) with models of direct siRNA-DNA interaction by envisioning that proximal intron splicing disrupts R-loop formation that is needed for direct siRNA-DNA base pairing to occur. However, the simplest explanation is that Ago-siRNA complexes are recruited to chromatin by binding solely to nascent RNA transcripts.

Beyond the evidence for Ago-siRNA base-pairing with nascent RNAs, protein-protein interactions with other chromatin-binding proteins are also implicated in Ago recruitment to chromatin. In $S$. pombe, nuclear Ago exists in a complex with the Ago hook-containing protein Tas 3 and the chromodomain protein Chp1. Chp1 binds to histones methylated on Lys9, thus recruiting Ago complexes to the chromatin mark that the complexes are required to maintain. In $A$. thaliana, Pol V physically interacts with SUVH2 and SUVH9, which bind methylated cytosines, and Ago can physically interact with the Pol V largest subunit or the Pol V interactor SPT5L (Holoch and Moazed 2015). Thus, in both organisms, Ago participates in protein-protein interactions with other chromatin-associated proteins at sites of TGS. Artificially tethering Tas3 to nascent RNA in $S$. pombe or tethering SUVH2 to DNA in $A$. thaliana is sufficient to bring about establishment of histone H3K9 methylation or cytosine methylation, respectively, in the absence of initiating siRNAs (Buhler et al. 2006; Johnson et al. 2014). However, not all components of a given silencing complex appear to be equally effective at nucleating silencing, as the tethering of Chp1 or Agol in $S$. pombe could not establish TGS de novo (Buhler et al. 2006).

Understanding the relative importance of RNA-RNA and protein-protein interactions in the establishment and maintenance of histone or cytosine methylation marks is clearly a question of ongoing interest. Future efforts to biochemically dissect the timing and order of siRNA-nucleic acid base-pairing interactions and interactions between Ago and its interacting protein partners will be needed to continue to decipher the complexities of siRNA and Ago involvement in TGS.

\section{Acknowledgments}

Work in the Pikaard laboratory is supported by funds to C.S.P. as an Investigator of the Howard Hughes Medical Institute and from the Gordon and Betty Moore Foundation. J.M.W. received support from National Institutes of Health departmental training grant T32GM007757, and the National Institute of General Medical Sciences of the National Institutes of Health under award number F31GM116346. The content of this work is solely the responsibility of the authors and does not necessarily represent the official views of the National Institutes of Health, Howard Hughes Medical Institute, or Gordon and Betty Moore Foundation.

\section{References}

Buhler M, Verdel A, Moazed D. 2006. Tethering RITS to a nascent transcript initiates RNAi- and heterochromatin-dependent gene silencing. Cell 125: 873-886.

Holoch D, Moazed D. 2015. RNA-mediated epigenetic regulation of gene expression. Nat Rev Genet 16: 71-84.

Irvine DV, Zaratiegui $\mathrm{M}$, Tolia NH, Goto DB, Chitwood DH, Vaughn MW, Joshua-Tor L, Martienssen RA. 2006. Argonaute slicing is required for heterochromatic silencing and spreading. Science 313: 1134-1137.

Johnson LM, Du J, Hale CJ, Bischof S, Feng S, Chodavarapu RK, Zhong X, Marson G, Pellegrini M, Segal DJ, et al. 2014. SRAand SET-domain-containing proteins link RNA polymerase V occupancy to DNA methylation. Nature 507: 124-128.

Motamedi MR, Verdel A, Colmenares SU, Gerber SA, Gygi SP, Moazed D. 2004. Two RNAi complexes, RITS and RDRC, physically interact and localize to noncoding centromeric RNAs. Cell 119: 789-802.

Nakama M, Kawakami K, Kajitani T, Urano T, Murakami Y. 2012. DNA-RNA hybrid formation mediates RNAi-directed heterochromatin formation. Genes Cells 17: 218-233.

Pikaard CS, Haag JR, Pontes OM, Blevins T, Cocklin R. 2012. A transcription fork model for Pol IV and Pol V-dependent RNA-directed DNA methylation. Cold Spring Harb Symp Quant Biol 77: 205-212.

Shimada Y, Mohn F, Bühler M. 2016. The RNA-induced transcriptional silencing complex targets chromatin exclusively via interacting with nascent transcripts. Genes Dev 30: 2571-2580.

Wendte JM, Pikaard CS. 2016. The RNAs of RNA-directed DNA methylation. Biochim Biophys Acta. doi: 10.1016/j.bbagrm. 2016.08.004.

Wierzbicki AT, Ream TS, Haag JR, Pikaard CS. 2009. RNA polymerase $\mathrm{V}$ transcription guides ARGONAUTE4 to chromatin. Nat Genet 41: 630-634.

You W, Lorkovic ZJ, Matzke AJ, Matzke M. 2013. Interplay among RNA polymerases II, IV and V in RNA-directed DNA methylation at a low copy transgene locus in Arabidopsis thaliana. Plant Mol Biol 82: 85-96. 


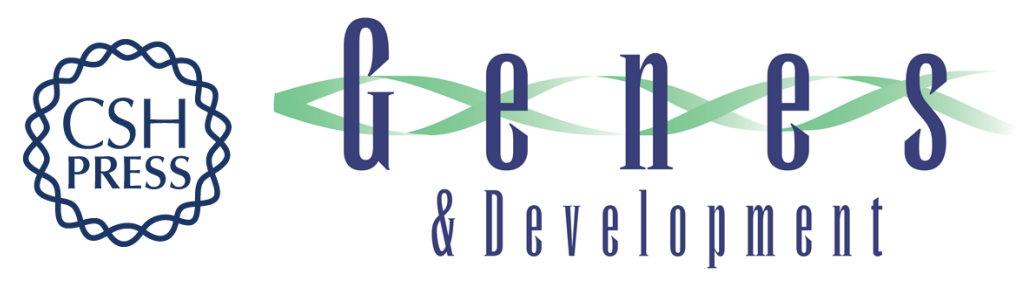

\section{Targeting Argonaute to chromatin}

Jered M. Wendte and Craig S. Pikaard

Genes Dev. 2016, 30:

Access the most recent version at doi:10.1101/gad.294900.116

\section{Related Content The RNA-induced transcriptional silencing complex targets chromatin exclusively via interacting with nascent transcripts Yukiko Shimada, Fabio Mohn and Marc Bühler \\ Genes Dev. December , 2016 30: 2571-2580}

References This article cites 11 articles, 3 of which can be accessed free at:

http://genesdev.cshlp.org/content/30/24/2649.full.html\#ref-list-1

Articles cited in:

http://genesdev.cshlp.org/content/30/24/2649.full.html\#related-urls

Creative This article is distributed exclusively by Cold Spring Harbor Laboratory Press for the first Commons License six months after the full-issue publication date (see http://genesdev.cshlp.org/site/misc/terms.xhtml). After six months, it is available under a Creative Commons License (Attribution-NonCommercial 4.0 International), as described at http://creativecommons.org/licenses/by-nc/4.0/.

Email Alerting Receive free email alerts when new articles cite this article - sign up in the box at the top Service right corner of the article or click here.

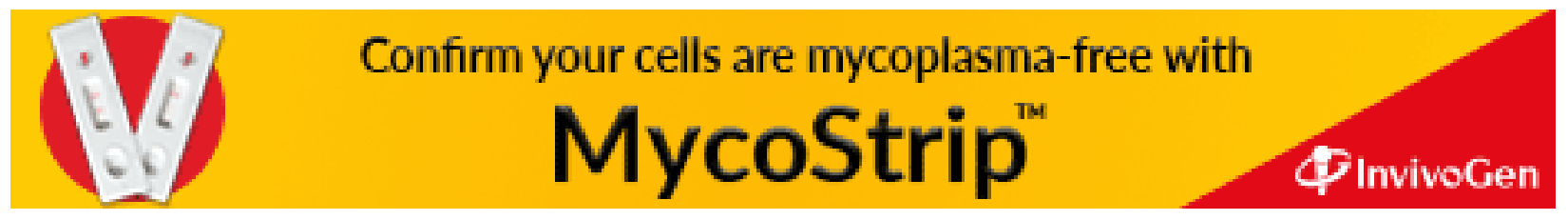

